TÄ̈ CHÍ PHAU் TRIEÅ KH\&CN, TÄ̈ 16, SOÁK1- 2013

\title{
STUDY ON THE DEPOSITION OF AMORPHOUS SILICON AND ITO THIN FILMS FOR HETEROJUNCTION SOLAR CELL APPLICATION
}

\author{
Dang Mau Chien, Bui Thanh Tung, Le Thanh Hung, Hoang Ngoc Vu, Tran Ngoc Linh, Truong \\ Lan and Nguyen Tran Thuat \\ Laboratory for Nanotechnology, Vietnam National University - Ho Chi Minh City \\ (Manuscript Received on April $5^{\text {th }}, 2012$, Manuscript Revised May 15 $5^{\text {th }}, 2013$ )
}

ABSTRACT: In the heterojunction with intrinsic thin-layer (HIT) solar cell structure studied in this work, an intrinsic amorphous silicon (a-Si) layer followed by a n-type amorphous silicon was deposited on a p-type Czochralski (CZ) monocrystalline silicon (c-Si) wafer by plasma enhanced chemical vapor deposition (PECVD) method to form an heterojunction device. Then, indium tin oxide (ITO) layer was formed by DC magnetron sputtering as the top electrode and the anti-reflection coating layer. In order to obtain the high efficiency heterojunction structure, two important aspects were focused: improving the passivation properties of $a-S i / c-S i$ heterojunction and reducing the light absorption and the sheet resistance of ITO layers. It was found that hydrogenated amorphous silicon (aSi:H) layers can be grown at low substrate temperature, about $200^{\circ} \mathrm{C}$. High-quality ITO layers with the sheet resistance less than $15 \mathrm{ohm} / \mathrm{sq}$ and the transmittance of about 70\%, can be deposited at relatively low DC power (50W).

Keyword: heterojunction, PECVD, magnetron sputtering, a-Si:H, ITO.

\section{INTRODUCTION}

An heterojunction is the interface that occurs between two layers or regions of semiconductor with dissimilar crystalline structures, thus different band gaps. Theheterojunction with intrinsic thin-layer (HIT) structure was first proposed and used by Sanyo in 1992 and have been developing to the state-of-the-art high efficiency solar cells based on both n-type and p-type silicon wafer $[1,2,3]$. It has a feature that can reduce recombination loss of the free carriers by surrounding the most carrier generation layer of single thin crystalline silicon (c-Si) with high quality ultra- thin amorphous silicon (a-Si) layer. The recombination loss occurs when the negatively charged and positively charged carriers that are produced within the solar cell combine, causing a loss in the electrical current produced by the solar cell and hence a decrease in the overall output of the solar cell.

In the HIT solar cell structure studied, an intrinsic a-Si:H layer was deposited on a p-type Czochralski (CZ) monocrystalline silicon (c-Si) wafer using plasma enhanced chemical vapour deposition (PECVD) method. In addition, indium tin oxide (ITO) layer was formed by DC magnetron sputtering as the top electrode and the anti-reflection coating layer. 
The process flow of fabrication of heterojunction solar cell is presented in Fig. 1. To obtain higher efficiency with the heterojunction structure, two aspects werefocused: improving the passivation properties of a-Si/c-Si heterojunction and reducing the light absorption and the sheet resistance of ITO layers.

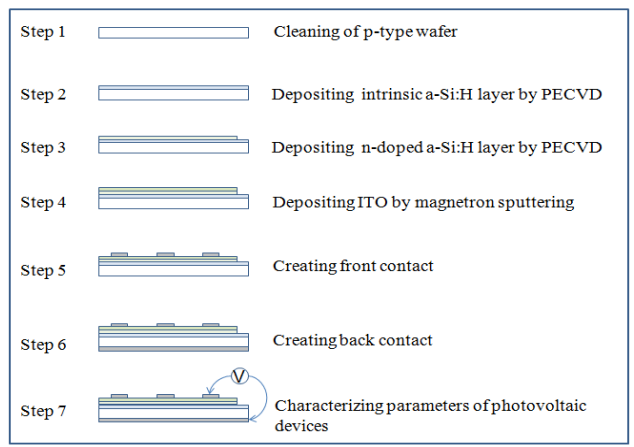

Figure 1. The fabrication process of heterojunction solar cells studied at LNT.

In the visible part of the solar spectrum, a$\mathrm{Si}$ absorbs almost 100 times more than c-Si. However, its energy conversion efficiency is not good because of the random network of silicon. This configuration causes the formation of dangling bonds [4]. When moving inside the thin film layer, electrons of electron-hole pairs are easily caught by those bonds acting like free carrier traps. This phenomenon makes the energy conversion efficiency of a-Si based solar cells quite low. For improving the energy conversion, hydrogen atoms were added in the random network of silicon in order to passivate these dangling bonds through chemical reactions between hydrogen $\left(\mathrm{H}_{2}\right)$ and silane $\left(\mathrm{SiH}_{4}\right)$ in the deposition gaseous phase and consequently hydrogenated amorphous silicon (a-Si:H) was obtained.

It is shown that the open circuit voltage $\left(\mathrm{V}_{\mathrm{oc}}\right)$ of solar cells depends much on the minority free carrier recombination rate at the rear surface [6]. In fact, the high $\mathrm{V}_{\mathrm{oc}}$ of the HIT solar cells has been achieved primarily by the effective passivation of defects on c-Si surface with high-quality intrinsic a-Si:H. In n-doped a-Si:H/p-type c-Si heterojunction without intrinsic a-Si:H layers, electrical drift current is caused by many localized states in the doped layer. As a result, it is quite difficult to obtain solar cells with high $\mathrm{V}_{\mathrm{oc}}$. By using the highquality intrinsic a-Si:H layer with good passivation of hydrogen, tunneling of free carriers to mid-gap trapping states can be suppressed and the excellent interface properties can be obtained. Therefore, in order to obtain a higher $\mathrm{V}_{\mathrm{oc}}$, it is very important to have high quality intrinsic a-Si:H layers and excellent a-Si:H/c-Si interfaces [7].

Since the conductance of a-Si:H is quite low, for collecting light-generated free carriers from a-Si:H, the contact grid must be very dense. This dense contact will in other hand reduce the light-exposed surface and compromise the efficiency of a-Si:H based solar cell. Due to this inconvenience, ITO is used as transparent conductive contacts because of its high electrical conductivity and high transparency in the visible light wavelength range [5]. In addition, for a higher short circuit current $\left(\mathrm{I}_{\mathrm{sc}}\right)$, optical loss such as 
TÄ̈ CHÍ PHAU் TRIEÅ KH\&CN, TAR̈ 16, SOÁK1- 2013

light absorption in the ITO layer must be reduced [7].

\section{EXPERIMENTAL PROCEDURE}

\subsection{Deposition process and method}

As presented above, for creating a high $\mathrm{V}_{\mathrm{oc}}$ and $I_{\mathrm{sc}}$ solar cells, a fabrication process as following was studied:

1) Cleaning c-Si surface, including native oxide removal before intrinsic a-Si:H deposition.

2) Depositing high-quality intrinsic a-Si:H layers by using ultra high pure gas precursors (with lowering the plasma and thermal damage to the c-Si surface during deposition process).

The PECVD was chosen for depositing the intrinsic a-Si:H because the energy transfer process in plasma phase is really slow. The temperature of deposition process is low and this reduces thermal damage to the c-Si surface during fabrication process. The ion bombardment phenomenon on the surfaces exposed to plasma makes the high-density thin films, reducing the porosity of deposited layers. A significant benefit of plasma deposition is the ability to easily clean the c-Si surface.

In this work the magnetron sputtering was chosen for depositing ITO layers because deposited films have a composition close to that of the source material and a better adhesion on the substrate than evaporated films. Morever, advanced processes such as epitaxial growth are possible.

\subsection{Materials and equipment}

The silicon wafer has been fabricated by Okmetic Company by using Czochralski crystal growing method with the parameters: diameter of $100 \pm 0.5 \mathrm{~mm}$, p-type silicon doped Boron, crystalline orientation of the surface (100), thickness of $525 \pm 25 \mu \mathrm{m}$, resistivity of 2-10 ohm.cm.

For the cleaning of the wafers, these latters were dipped in piranha solution $\left(\mathrm{H}_{2} \mathrm{SO}_{4} / \mathrm{H}_{2} \mathrm{O}_{2}\right.$ (30\%) volume ratio 3:1) in 15 minutes, and then in acetone solution in 5 minutes and finally in ethanol solution. After that, the wafers were dipped in HF $1 \%$ solution followed by rinsing in DI water and dried by pure nitrogen gas quickly prior to the deposition.

The intrinsic a-Si:H layer was deposited by Elettrorava PECVD Cluster system, using a mixture of silane $\left(\mathrm{SiH}_{4}\right)$ and hydrogen $\left(\mathrm{H}_{2}\right)$ as gas precursors. The ITO layer was deposited by NIVEX 350 LEYBOLD Magnetron Sputtering system using the target of 2', diameter and of $6 \mathrm{~mm}$ thickness (fabricated by William company with the ratio of weight: $\operatorname{In}_{2} \mathrm{O}_{3} 90 \%$ and $\mathrm{SnO}_{2} 10 \%$ ).

For the intrinsic a-Si:H layers, films thicknesses were estimated by the fitting the spectroscopic ellipsometry spectrum using the DeltaPsi2 software provided by the UVISEL2 system. Film structures were observed by Raman spectroscopy with multi Gaussian adjustment. The auto polarization $\left(\mathrm{V}_{\mathrm{dc}}\right)$ was measured by the built-in voltmeter coupled with RF electrode. For the ITO layers, the 
results were obtained by using FilmTekTM 1000 equipment and Quadpro 4-point prober for measuring thickness and sheet resistance respectively. Finally, the reflection and transmittance properties of ITO thin films deposited on glass substrate were measured by Origin Jasco Spectrometer.

\section{RESULTS AND DISCUSSIONS}

\subsection{Depositing intrinsic a-Si:H layers by PECVD}

In process chamber of Elettrorava PECVD Cluster system, a mixture of silane and hydrogen was excited by Radio Frequency (RF) power generator to ignite plasma and to create ions and radicals in the gaseous phase. These ions and radicals diffuse to the substrate contributing to the deposition of hydrogenated amorphous silicon thin film [8].

Hydrogen atoms are added in the network of silicon in order to passivate dangling bonds through chemical reactions between atomic hydrogen on the surface of deposited layers. They also play the role of supplied energy carriers for the deposition reactions at the substrate surface. Hydrogen dilution ratio in gas mixture must be enough to passivate the dangling bonds as well as not be too much to cause the stress inside material structure [4].

Two series of samples were made at RF power density of 0.05 and $0.1 \mathrm{~W} / \mathrm{cm}^{2}$ with the reaction gas pressure change in the range from 0.3 to 2.7 Torr, other parameters were kept stable: $10 \mathrm{sccm}$ of $\mathrm{SiH}_{4}$ diluted in $90 \mathrm{sccm}$ of $\mathrm{H}_{2}$, substrate temperature of $200^{\circ} \mathrm{C}$, the interelectrode distance of about $20 \mathrm{~mm}$. Deposition time was chosen so that thin film's thickness is enough for the characterizing process but not too long because it can affect to quality of deposited layers. Therefore, the deposition duration of 15 minutes is appropriate for experiments.

\subsubsection{Thin film thickness and deposition rate}

The thicknesses of samples were obtained by the fitting the spectroscopic ellipsometry spectrum using the DeltaPsi2 software, then divide by deposition time (15 minutes) to deduce the deposition rate (Tab. 1).

Table 1. Thickness and deposition rate of samples

\begin{tabular}{|c|c|c|c|c|}
\hline \multirow{2}{*}{$\begin{array}{c}\text { Deposition } \\
\text { pressure } \\
\text { (Torr) }\end{array}$} & \multicolumn{2}{|c|}{$\begin{array}{c}\text { Power density of } \\
0.05 \mathrm{~W} / \mathrm{cm}^{2}\end{array}$} & \multicolumn{2}{c|}{$\begin{array}{c}\text { Power density of } \\
0.1 \mathrm{~W} / \mathrm{cm}^{2}\end{array}$} \\
\cline { 2 - 5 } & $\begin{array}{c}\text { Thickness } \\
\text { (nm) }\end{array}$ & $\begin{array}{c}\text { Deposition } \\
\text { rate } \\
(\mathrm{nm} / \mathrm{min})\end{array}$ & $\begin{array}{c}\text { Thickness } \\
(\mathrm{nm})\end{array}$ & $\begin{array}{c}\text { Deposition } \\
\text { rate } \\
(\mathrm{nm} / \mathrm{min})\end{array}$ \\
\hline 0.3 & 10.5 & 0.7 & & \\
\hline 0.6 & 84 & 5.6 & & 10.1 \\
\hline 0.9 & 91.5 & 6.1 & 151.5 & \\
\hline
\end{tabular}


TÄ̈ CHÍ PHAÙ TRIEÅ KH\&CN, TÄ̈ 16, SOÁK1- 2013

\begin{tabular}{|c|c|c|c|c|}
\hline 1.2 & 109.5 & 7.3 & 205.5 & 13.7 \\
\hline 1.5 & 141 & 9.4 & 304.5 & 20.3 \\
\hline 1.8 & 204 & 13.6 & 345 & 23 \\
\hline 2.1 & 201 & 13.4 & 408 & 27.2 \\
\hline 2.4 & 175.5 & 11.7 & 367.5 & 24.5 \\
\hline 2.7 & 100.5 & 6.7 & & \\
\hline
\end{tabular}

The deposition rate of intrinsic a-Si:H thin film is presented in Fig. 2. As shown in the figure, at low pressure (under 1 Torr), the deposition rate increases slowly with the increment of the total gas pressure caused by the increase of material density on plasma bulk. When the pressure ranging from 1 Torr to 1.8 Torr, the plasma powder begins to form with nano-size and decrease the free particles density. This is combined with increase of electronic temperature which enhances the electronic attachment reactions to create radicals in the gaseous plasma phase. As consequences, the deposition rate increases when the total pressure augments. At higher pressure (over 2.1 Torr), nanoparticles in plasma phase reach the critical density. They agglomerate together to form micro-size particles. These particles are normally negatively charged. They favor the attachments of radicals in plasma to the particles' surface. As a result, the deposition rate decreases.

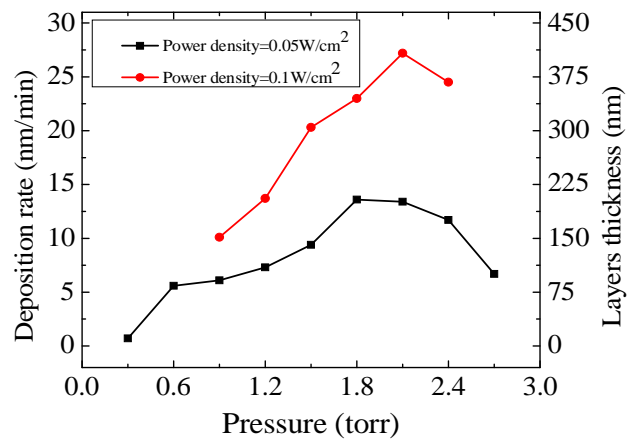

Figure 2. Thickness and deposition rate of intrinsic a-Si:H thin films as function of total gas pressure

(deposition time of $15 \mathrm{mn}$ )

These results have a good agreement with the plasma characteristic represented by RF auto polarization tension $\left(V_{d c}\right)$ values as shown in Fig. 3. This potential will saturate (reach to a constant value) when the coulomb repulsion is strong enough to compensate the momentum of electrons moving to RF electrode. During deposition process, if the density of radicals is so high, they can react together giving the formation of nanoparticles. These nanoparticles themselves can agglomerate when their density is higher than a threshold value. These latter reactions give the formation of silicon powder suspending in the plasma gaseous phase. With 
this powder, plasma loss its stability and $\mathrm{V}_{\mathrm{dc}}$ values change in an unstable way (see Fig. 3).

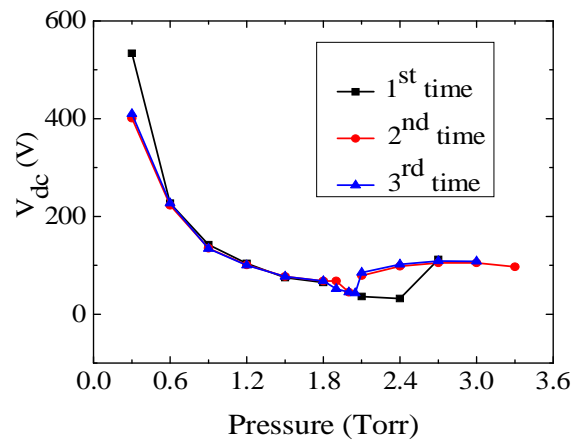

Figure 3. The RF auto polarization tension $\left(\mathrm{V}_{\mathrm{dc}}\right)$ on the RF electrode as function of total gas pressure

\subsubsection{Structural characteristic}

In this study, the structure characteristic of deposited samples shown in Tab. 1 was observed by Raman spectroscopy with multi Gaussian adjustment (Fig. 4).
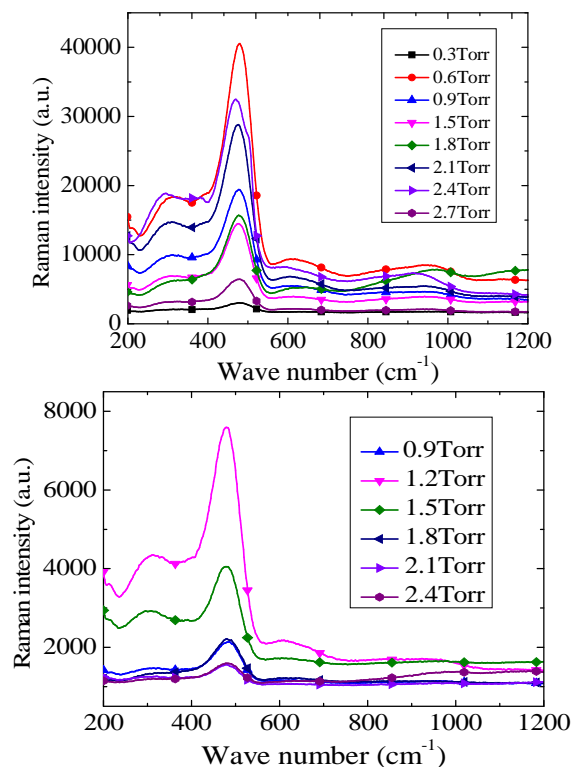

Figure 4. Raman spectra of intrinsic a-Si:H thin films deposited at RF power density of a) $0.05 \mathrm{~W} / \mathrm{cm}^{2}$ and b) $0.1 \mathrm{~W} / \mathrm{cm}^{2}$
It is foundthat all the Raman spectra which have the highest peak at the neighborhood of $480 \pm 3 \mathrm{~cm}^{-1}$ with the full width at half maximum (FWHM) value is about $70 \pm 5 \mathrm{~cm}^{-1}$ representing the vibration of $\mathrm{Si}-\mathrm{Si}$ bonds in random network and another peak at $630 \mathrm{~cm}^{-1}$ signifying the vibration of $\mathrm{Si}-\mathrm{H}$ bonds [9]. As a conclusion, these thin layers have the structure of hydrogenated amorphous silicon for both power density $0.05 \mathrm{~W} / \mathrm{cm}^{2}$ and $0.1 \mathrm{~W} / \mathrm{cm}^{2}$

Therefore, the RF power density of $0.05 \mathrm{~W} / \mathrm{cm}^{2}$ should be chosen in order to save the supply energy and to keep lower possibility of stress in deposited layer. In the HIT solar cell structure, because the intrinsic hydrogenated silicon thickness is often under $20 \mathrm{~nm}$ [4], we should chose the total gas pressure in the range from 0.6 to 1 Torr (the deposition rate is about $5-6 \mathrm{~nm} / \mathrm{min}$ and deposition time is about 3-4 minutes) for easy control of thickness. Moreover, at this pressure range, plasma is stable and plasma powder is not formed yet. Deposited layers are protected from the surface defects and have good quality.

\subsection{Depositing ITO layers by magnetron sputtering}

In this work, the experiments were set at the following fixed parameters: distance between target and substrate of $5 \mathrm{~cm}, \mathrm{DC}$ voltage of $500 \mathrm{~V}$, DC current of $700 \mathrm{~mA}$. The excited power $(P)$ was calibrated in the range of $30-60 \mathrm{~W}$ and the argon flow rate $(A r)$ was chosen from 4 to $8 \mathrm{sccm}$ to find out the most suitable conditions for the depositing ITO 
layers that can be applied in heterojunction solar cells [5].

In experiments, the thickness of ITO layers were tried to keep at $100 \mathrm{~nm}$ being appropriate for characterization of properties [5]. When the deposition process finished, the deposition time (t) was shown on machine. Therefore, the conductivity and optical characteristics of deposited layers depend on two parameters: excited power source and argon flow rate as presented in Table 2.

Table 2. Experiment conditions of ITO samples and deposition time

\begin{tabular}{|c|c|c|c|}
\hline $\begin{array}{c}\text { Sample } \\
\text { No }\end{array}$ & $\begin{array}{c}\mathrm{P} \\
(\mathrm{W})\end{array}$ & $\begin{array}{c}\text { Ar } \\
(\mathrm{sccm})\end{array}$ & $\begin{array}{c}\mathrm{t} \\
(\mathrm{min})\end{array}$ \\
\hline 1 & 30 & 4 & 14,7 \\
\hline 2 & 30 & 6 & 12,0 \\
\hline 3 & 30 & 8 & 17,0 \\
\hline 4 & 40 & 4 & 11,0 \\
\hline 5 & 40 & 6 & 13,0 \\
\hline 6 & 40 & 8 & 8,7 \\
\hline 7 & 50 & 4 & 8,5 \\
\hline 8 & 50 & 8 & 7,4 \\
\hline 9 & 50 & 4 & 7,8 \\
\hline 10 & 60 & 6 & 8,0 \\
\hline 11 & 60 & 8 & 9,4 \\
\hline 12 & 60 & & 6 \\
\hline
\end{tabular}

\subsubsection{Deposition rate}

The deposition rate can be defined by:

$r=\frac{d}{t}=\frac{100}{t}$

With $r$ : deposition rate $(\mathrm{nm} / \mathrm{min})$,

$d$ : thickness of ITO layers $(=100 \mathrm{~nm})$

$t$ : deposition time (min).

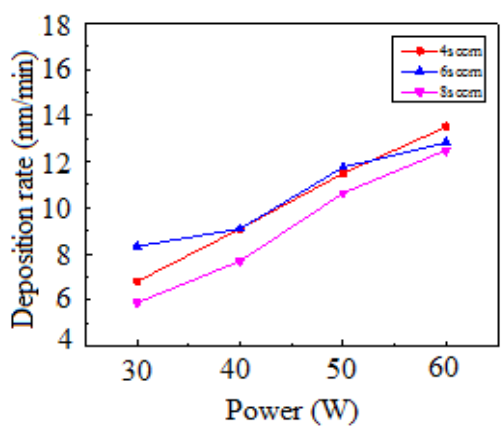

Figure 5. Deposition rate of ITO thin films as function of DC source power and argon flow rate

As shown in Fig. 5 that the deposition rate of ITO layers increases linearly with the DC source power when argon flow is kept constant. 
This could be explained by rising excited power, the energy of incident atoms on the target is higher that increases the number of ITO atom bombarded and deposited on the substrate. In addition, the deposition rate isn't strongly depended on the argon flow at the same excited power values.

\subsubsection{Conductivity characteristic}

In order to measure the sheet resistance, obtained samples above (No 1 - No 12) were used. It is found the sheet resistance is most stable at 50W excited power and the average value is about $12,3 \mathrm{ohm} / \mathrm{sq}$ (Fig. 6). If the excited power value is lower or higher, it will have some bad effects on the crystallinity of thin film layers and consequently the sheet resistance becomes unstable. In the other hand, the argon flow rate has no influence to the sheet resistance. So, the excited power should be kept constant at 50W which is suitable with the Ref. [5].

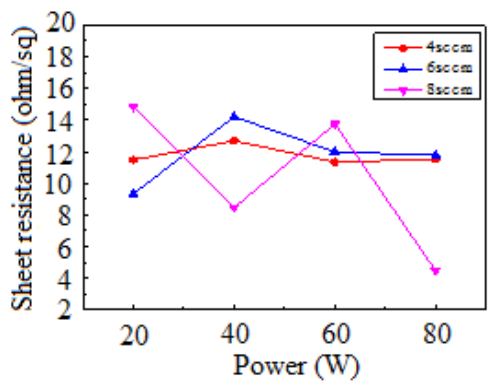

Figure 6. Sheet resistance of ITO thin fims of $100 \mathrm{~nm}$ thickness as function of excited power and argon flow rate.

\subsubsection{Optical characteristic}

For the evaluation of optical characteristic, samples No 7, 8, 9 (corresponding to $\mathrm{P}=50 \mathrm{~W}$ ) were taken for measuring the reflection and transmittance spectra. The obtained results are shown in Fig. $7 \& 8$.

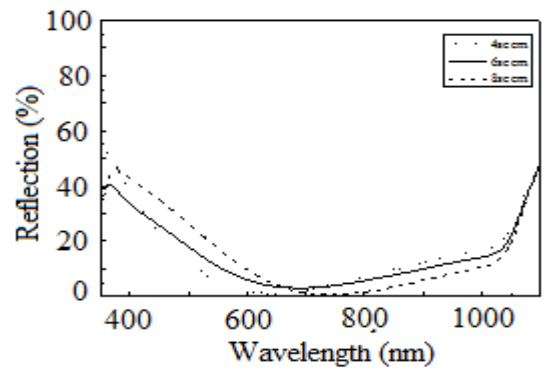

Figure 7. Reflection spectrum of ITO thin films deposited at 4, 6, 8sccm argon rate with 50W excited power.

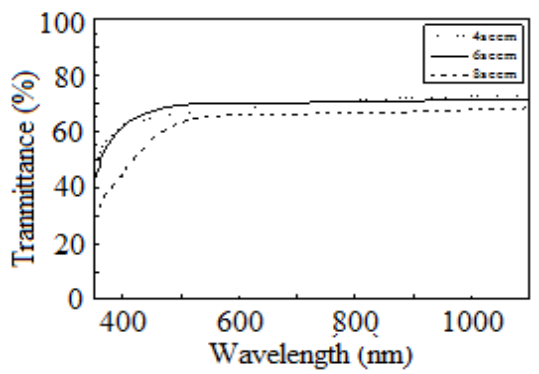

Figure 8. Transmittance spectrum of ITO thin films deposited at 4, 6, $8 \mathrm{sccm}$ argon rate with $50 \mathrm{~W}$ excited power

From the reflection and transmittance spectra, the total reflection $R_{\text {total }}$ and total transmittance $T_{\text {total }}$ were calculated as following:

From the spectrum irradiation data of the National Renewable Energy Laboratory (NREL), we have the total energy $E_{i}$ for each wavelength $\lambda_{i}$. Using the equation $E=\frac{h c}{\lambda}$ (1). It was calculated the energy of one photon $e_{i}$ at wavelength $\lambda_{i}$. 
With $h$ : Plank constant $\left(6,626.10^{-34} \mathrm{~J} . \mathrm{s}\right)$.

$c$ : velocity of light $\left(3.10^{8} \mathrm{~m} / \mathrm{s}\right)$.

$\lambda$ : wavelength.

Dividing the total energy $E_{i}$ by the energy of one photon $e_{i}$, we get the incident photons $n_{i}$ at each wavelength $\lambda_{i}$.

$$
n_{i}=\frac{E_{i}}{e_{i}}(2)
$$

Lastly, the total reflection index $R_{\text {total }}$ and the total transmittance index $\left(\mathrm{T}_{\text {total }}\right)$ will be calculated by using following formulas

$$
\begin{aligned}
R_{\text {total }}= & \frac{\sum_{n} r_{i} n_{i}}{n} \\
T_{\text {total }} & =\frac{\sum_{n} t_{i} n_{i}}{n}
\end{aligned}
$$

With $r_{i}, t_{i}$ : the reflection and transmittance index at wavelength $\lambda_{i}$ (got from Figs. 7,8 ).

$n_{i}$ : the incident photon at wavelength $\lambda_{i}$

$n$ : the total incident photon

The obtained calculation results are presented in Table 3.

Table 3. Calculation results of the total reflection $\mathrm{R}_{\text {total }}$ and total transmittance $\mathrm{T}_{\text {total }}$.

\begin{tabular}{|c|c|c|c|c|}
\hline $\begin{array}{c}\text { Sample } \\
\text { No }\end{array}$ & $\begin{array}{c}\mathrm{P} \\
(\mathrm{W})\end{array}$ & $\begin{array}{c}\mathrm{Ar} \\
(\mathrm{sccm})\end{array}$ & $\begin{array}{c}\mathrm{R}_{\text {total }} \\
(\%)\end{array}$ & $\begin{array}{c}\mathrm{T}_{\text {total }} \\
(\%)\end{array}$ \\
\hline 7 & 50 & 4 & 15,45 & 69,59 \\
\hline 8 & 50 & 6 & 15,88 & 69,87 \\
\hline 9 & 50 & 8 & 15,40 & 64,98 \\
\hline
\end{tabular}

As shown in Fig. 7 and Tab. 3, the $R_{\text {total }}$ of deposited ITO layers doesn't depend on the argon flow rate. Fig. 8 and Tab. 3 show also that $T_{\text {total }}$ of ITO thin films deposited with 4 and $6 \mathrm{sccm}$ argon are higher and more stable than which of $8 \mathrm{sccm}$ argon. However, at $4 \mathrm{sccm}$ argon flow rate, the plasma was flashing in sputtering process and this phenomenon could be affect to the uniformity of deposited layers. So, $6 \mathrm{sccm}$ argon flow rate should be chosen. And the obtained transmittance index is about $70 \%$ (see Tab. 3).

\section{CONCLUSIONS}

In this work, we studied materials for the fabrication process of silicon heterojunction solar cells. High-quality hydrogenated amorphous silicon thin films were successfully deposited by PECVD. It was found an optimal condition for deposition: $0.05 \mathrm{~W} / \mathrm{cm}^{2} \mathrm{RF}$ power, $10 \mathrm{sccm} \mathrm{SiH}_{4}$ diluted in $90 \mathrm{sccm} \mathrm{H}_{2}, 200^{\circ} \mathrm{C}$ substrate temperature, $20 \mathrm{~mm}$ inter-electrode distance, and reaction gas pressure in the range of 0.6 to 1 Torr.

Furthermore, we also optimized the deposition of ITO thin films on silicon substrate with the following parameters: argon flow of $6 \mathrm{sccm}$, DC power of 50W and ITO thickness is about $100 \mathrm{~nm}$. The ITO layers had the sheet resistance under $15 \mathrm{ohm} / \mathrm{sq}$ and the transmittance of about $70 \%$.

Both obtained a-Si:H and ITO layers are appropriate for silicon heterojunction solar cells. It will be experimented in the near future the doping process to create a n-type amorphous silicon layer by using a gas mixture containing $\mathrm{PH}_{3}$, which finally forms the upmost structure of silicon heterojunction solar cells. 


\title{
NGHIÊN CÚU QUÁ TRÌNH LĂNG ĐỌNG MÀNG MỎNG SILIC VÔ ĐỊNH HÌNH VÀ MÀNG DẪN ĐIỆN TRONG SUỐT ITO ÚNG DỤNG VÀO CÂU TRÚC PIN MẶT TRÒ̀I MÀNG MỎNG MỐI NỐI DỊ THỄ
}

\author{
Đặng Mậu Chiến, Bùi Thanh Tùng, Lê Thanh Hùng, Hoàng Ngọc Vũ, Trần Ngọc Linh, Trương \\ Lân và Nguyễn Trần Thuật \\ Phòng Thí Nghiệm Công Nghệ Nano, Đại học quốc gia Thành phố Hồ Chí Minh
}

TÓM TÁT: Trong cấu trúc pin mặt trời với lớp tiếp xúc dị thể ở nghiên cứu này, lớp màng mỏng silic vô định hình pha tạp loại $n$ được phủ lên đế wafer silic tinh thể loại p bằng phuơng pháp lắng đọng hoi hóa học tăng cuờng plasma (PECVD) để tạo mối nối p-n. Một lớp màng mỏng silic vô định hình không pha tạp (a-Si:H) đóng vai trò lớp hấp thu nằm ở giũa. Lớp màng dẫn điện trong suốt Indium Tin Oxide (ITO) đóng vai trò là lớp dẫn điện và chống phản xa được phủ bằng phương pháp phún xa magnetron. Hai hiệu ưng co bản được chú trong để tăng hiệu suất của pin là thu động hóa tốt bề mặt tiếp xúc a-Si/c-Si. Đồng thời giảm khả năng hấp thu ánh sáng và điện trở bề mặt của lớp màng ITO. Kết quả nghiên cứ đã chế tạo được lớp màng a-Si chất luợng khá tốt ở điều kiện nhiệt độ thấp $200^{\circ} \mathrm{C}$. Lớp ITO chất luợng cao với điện trở bề mặt duới $15 \mathrm{ohm} / \mathrm{sq}$, độ truyền qua $70 \%$ được lắng đọng với công suất plasma khá thấp.

Tù khóa: Mối nối dị thể, PECVD, phún xạ magnetron, a-Si:H, ITO.

\section{REFERENCES}

[1]. Dirk-Holger Neuhaus and Adolf Münzer, Review Article: Industrial Silicon Wafer Solar Cells, Advances in Optoelectronics, Article ID 24521, 15 pages, doi:10.1155/2007/24521 (2007).

[2]. Martin A. Green, Keith Emery, Yoshihiro Hishikawa and Wilhelm Warta, Research: Short communication: accelerated publication, Solar cell efficiency tables (version 37), Prog. Photovolt: Res. Appl., 19:84-92 (2011).

[3]. Maruyama E, Terakawa A, Taguchi M, Yoshimine Y, Ide D, Baba T, Shima M,
Sakata H, Tanaka M, Sanyo's challenges to the development of high-efficiency HIT solar cells and the expansion of HIT business, 4th World Conference on Photovoltaic Energy Conversion (WCEP4), Hawaii, (May 2006).

[4]. Jef Poortmans and Vladimir Arkhipov, Thin Film Solar Cells Fabrication, Characterization and Applications, IMEC, Leuven, Belgium, John Willey \& Sons Ltd (2006).

[5]. X.Deng, G.Miller, R.Wang, L.Xu, A.D.Compaan, Study of sputter deposition of ITO films for a-Si:H NIP Solar Cells, 2nd World Conference and Exhibition on 


\section{TAP̈ CHÍ PHAÙ TRIEÂ KH\&CN, TAR̈ 16, SOÁK1- 2013}

Photovoltaic Solar Energy Conversion 6 10, Vienna, Austria(July 1998).

[6]. S.W. Glunz, Review Article: HighEfficiency Crystalline Silicon Solar Cells, Advances in Optoelectronics, Article ID 97370, 15 pages, doi:10.1155, 97370 (2007).

[7]. Yasufumi Tsunomura, Yukihiro Yoshimine, Mikio Taguchi, Toshiaki Baba, Toshihiro Kinoshita, Hiroshi Kanno, Hitoshi Sakata, Eiji Maruyama and Makoto Tanaka, Twenty-two percent efficiency HIT solar cell,Solar Energy Materials and Solar Cells, 93, 6-7, 670-

673, 17th International Photovoltaic
Science and Engineering Conference (June 2009).

[8]. Jessica M. Owens, DaxingHan, Baojie Yan, Jeffrey Yang, Kenneth Lord and Subhendu Guha, Micro-Raman Studies of Mixed-phase Hydrogenated Silicon Solar Cells,Materials Research Society Proc. Vol. 762 ( 2003).

[9]. U. R. Kortshagen, U. V. Bhandarkar, M. T. Swihart and S. L. Girshick, Generation and growth of nanoparticles in lowpressure plasmas, Pure Appl. Chem., Vol. 71, 10, 1871-1877, Printed in Great Britain (1999). 